\title{
Gran hematoma de pared abdominal secundario a colocación de trocar
}

\author{
Z. Valera Sánchez, S. Morales Conde, F. López Bernal y H. Cadet Dussort \\ Servicio de Cirugía General. Hospitales Universitarios Virgen del Rocío. Sevilla
}

\section{CASO CLÍNICO}

Varón de 61 años con antecedente de DMNID que ingresa para colecistectomía laparoscópica programada que se realiza con 4 trocares. El postoperatorio cursa con normalidad, presentado al tercer día de la intervención un golpe de tos seguido de un abombamiento de todo el recto anterior derecho, muy doloroso y de consistencia dura. Se realiza TAC urgente donde se objetiva aumento de la atenuación y volumen del recto anterior del abdomen con un diámetro antero-superior de unos 6 x $20 \mathrm{~cm}$ en sentido craneocaudal, compatible con hematoma de gran volumen en recto anterior derecho posiblemente secundario a lesión por trocar de los vasos epigástricos. Inicialmente se maneja de manera conservadora realizando controles del hematocrito que cae hasta dos puntos sin necesidad de transfusión, y finalmente drena espontáneamente a través del orificio del trocar supraumbilical. El paciente es dado de alta a los 28 días postintervención. Diagnóstico: gran hematoma de pared abdominal (Fig. 1).

\section{COMENTARIOS}

Los hematomas por rotura de los vasos epigástricos secundaria a la colocación de los trocares no son una patología poco frecuente, en la mayoría de los casos estos pueden ser tratados con medidas conservadoras hasta su completa reabsorción. Cuando hay signos de sobreinfección pueden requerir drenaje percutáneo o quirúrgico. El correcto posicionamiento de los trocares evitando el deslizamiento de los mismos a través del grosor de la pared abdominal evitaría la potencial lesión de los vasos epigástricos.

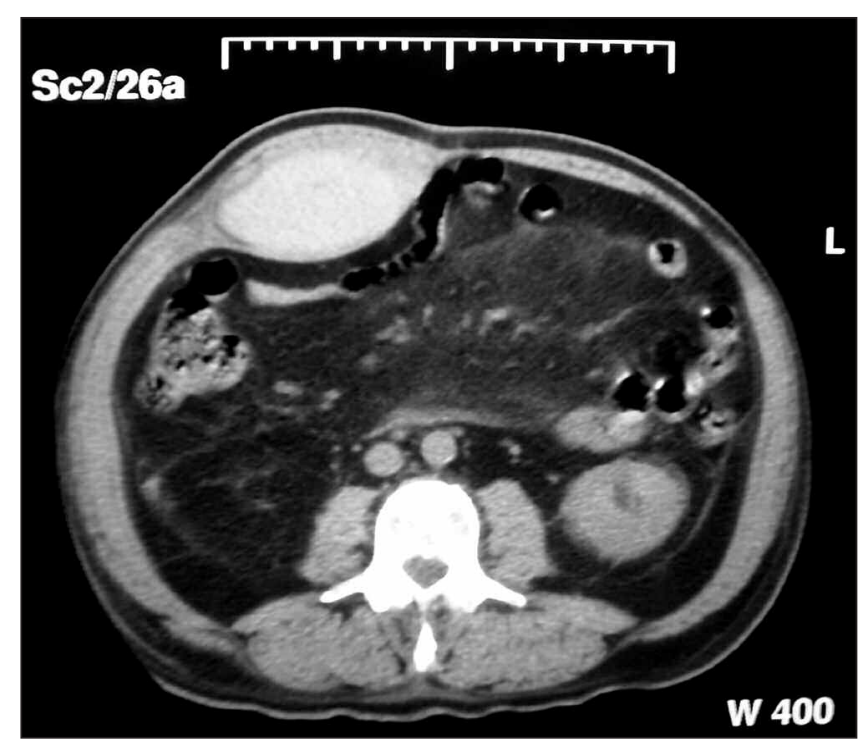

Fig. 1. TAC abdomen: gran hematoma en la vaina del recto derecho anterior con abombamiento del peritoneo y del paquete intestinal. 